\title{
STRIATIONS ON MINOR FAULTS AND THE STRUCTURE OF THE PARMEENER SUPER-GROUP NEAR HOBART, TASMANIA
}

\author{
by R.F. Berry and M.R. Banks
}

(with 3 text-figures)

BERRY, R.F. \& BANKS, M.R., 1985 (31:vii): Striations on minor faults and the structure of the Parmeener Super-group near Hobart,Tasmania. Pap. Proc. R. Soc. Tasm. 119:23-29. https://doi.org/10.26749/rstpp.119.23 ISSN0080-4071. University of Tasmania, Hobart, Tasmania, Australia, 7000 .

Fault striations were measured on 104 minor faults within the Parmeener Super-group near Hobart. The fault striations probably reflect the complex movement history on adjacent large faults. Sophisticated numerical modelling of the regional stress systems which produced these striations indicated at least $t$ wo phases of faulting. The earlier phase was probably due to compression from the NNW in the Mesozoic and produced strike slip faults striking $100^{\circ}$ and $170^{\circ}$. The later phase of faulting was caused by extension to wards the ENE in the Early to Middle Tertiary and reactivated most of the early phase faults striking $170^{\circ}$, as normal dip slip faults. A small number of fault striations could not be attributed to either of these events.

Key Words: striations, faults, Mesozoic, Cainozoic, Tasmania.

\section{INTRODUCTION}

The Parmeener Super-group (Late Carboniferous to Late Triassic) is a relatively thin (less than $1.5 \mathrm{~km}$ ) sequence of sedimentary rocks, usually described as sub-horizontal. Rocks of the Supergroup were faulted during dolerite intrusion in the Mid Jurassic (McDougall 1961), Evernden \& Richards 1962) and during extensional tectonics beginning in the Late Cretaceous (Moore et al., 1984). Banks (1962, pp. 211-213) suggested that all the variation in bedding orientation could not be attributed to fault drag and fault block rotation but support for an independent fold phase has not occurred

The relationship between faulting, folding, jointing and the geometry of dolerite intrusions remains unclear. We have attempted to clarify these relationships in the Hobart area by studying the distribution and orientation of striations on minor faults. Numerical methods were used to relate these striations to the stress environment at the time of their formation. The stress system is correlated with other structures to generate a coherent view of the structural history of the Parmeener Super-group.

\section{METHOD}

A field study of fault striations has not been previously reported from the Parmeener Supergroup. Conventional wisdom is that all the faults are related to normal faulting but this has never been convincingly demonstrated. Many of the faults show normal dip slip displacements but in the shallowly dipping beds of the Super-group strike slip displacements are not easily demonstrated.

Fault striations are very common on fractures within the strongly lithified sandy mudstones of the Super-group, especially in the Fern tree Mudstone. The striations were only observed in relatively young excavations, such as roadcuttings, within the sandy mudstones. Only three striations were obtained from any other rock units in this study and they were from calcite-veined fractures in dolerite.

Most of the striations were obtained from faults with less than one metre displacement. The large scale faults in the Parmeener Super-group are seldom exposed well enough for fault striations to be obtained directly. The use of small fractures to identify the regional stress system introduces the possibility of errors due to local stress variations such as with Reidel shears but we have not found any evidence for this type of stress variation in our results. This observation is compatible with the conclusions of Angelier (1984) that the scale of faulting studied does not influence the pattern observed.

Quantitative computer-aided methods for the interpretation of the fault plane striations have been suggested by several authors (e.g. Carey and Brunier 1974, Armijo and Cisternas 1978, Angelier et al. 1981, Etchecopar et al. 1981). The basic assumptions are that the local stress tensor on the 


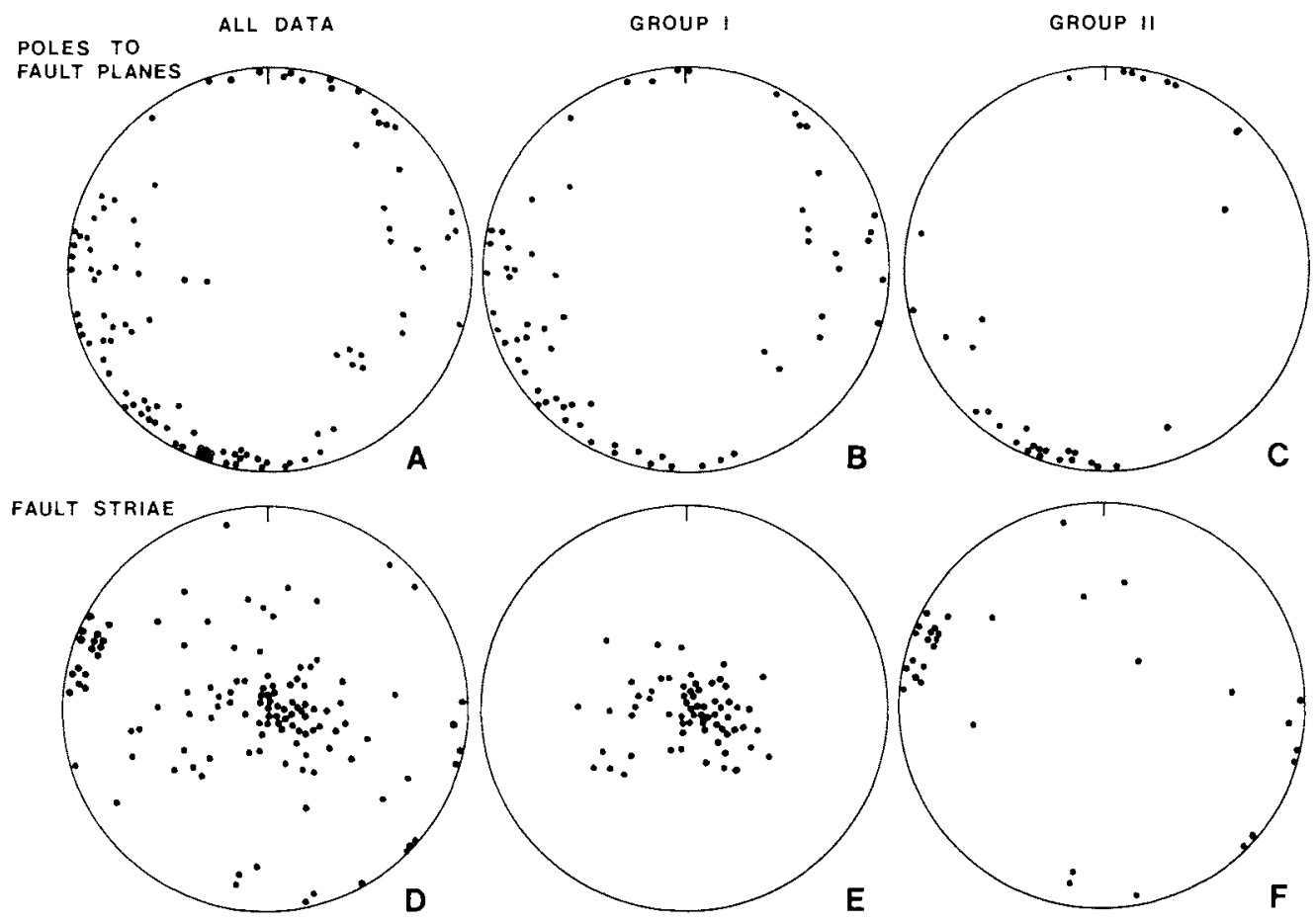

FIG. 1 - Lower hemisphere equal area projection of fault planes and fault striations from the Hobart area. All data collected are shown in A and D while Group I shows all the poles to faults (B) and striations (E) used for solution of extensional stress system and Group II is all poles to fault plane (C) and striations (F) used to obtain NNW compressional solution.

fault plane is parallel to the regional stress tensor and that the direction and sense of slip is parallel to the maximum resolved shear stress direction on the plane. We have developed a set of computer programs of the type described by Etchecopar et al. (1981) and using IMSL library routines to find the stress tensor compatible with any set of fault striations.

The numerical method can be worked in two directions. The program "STRIA" finds the stress tensor which has the lowest sum of the squares of angularerrors between the predicted and measured striations direction for each plane. Where striations from more than one event are included, outliers are eliminated automatically. The second program "STRIA/TEST" starts from a predicted stress tensor and looks for the nearest stress tensor which is an exact fit to each of the fault striations measured. This provides a useful test of the stability of the solutions obtained. Both these programs are as described by Etchecopar et al. (1981) except that they do not attempt to predict the sense of motion This limitation was made because we do not have a reliable measure of the sense of motion for $95 \%$ of our fault striations. This leaves an a mbiguity in the stress tensor which we resolved by consideration of qualitative data.

\section{FAULT STRIATIONS}

The fault striations were collected in two groups. The first 80 striations were analysed and then we collected a further 43. No significant changes occurred in the overall result due to this addition which suggests this is a representative sample for the Hobart area. All the fault plane and striations orientations are shown in fig. 1. The faults are mainly steeply dipping and include all strike directions. The E striking faults are all nearly vertical, suggesting a strike slip origin which is confirmed by the large number of horizontal fault striations a mongst this group. The $\mathrm{N}$ striking fa ults have more variable dips but are mainly stecp, suggesting both normal and strike slip faults. The majority of striations on these faults indicate dip slip motions. Where the sense of motion could be determined these faults had a normal sense of displacement. The NE striking faults have only 


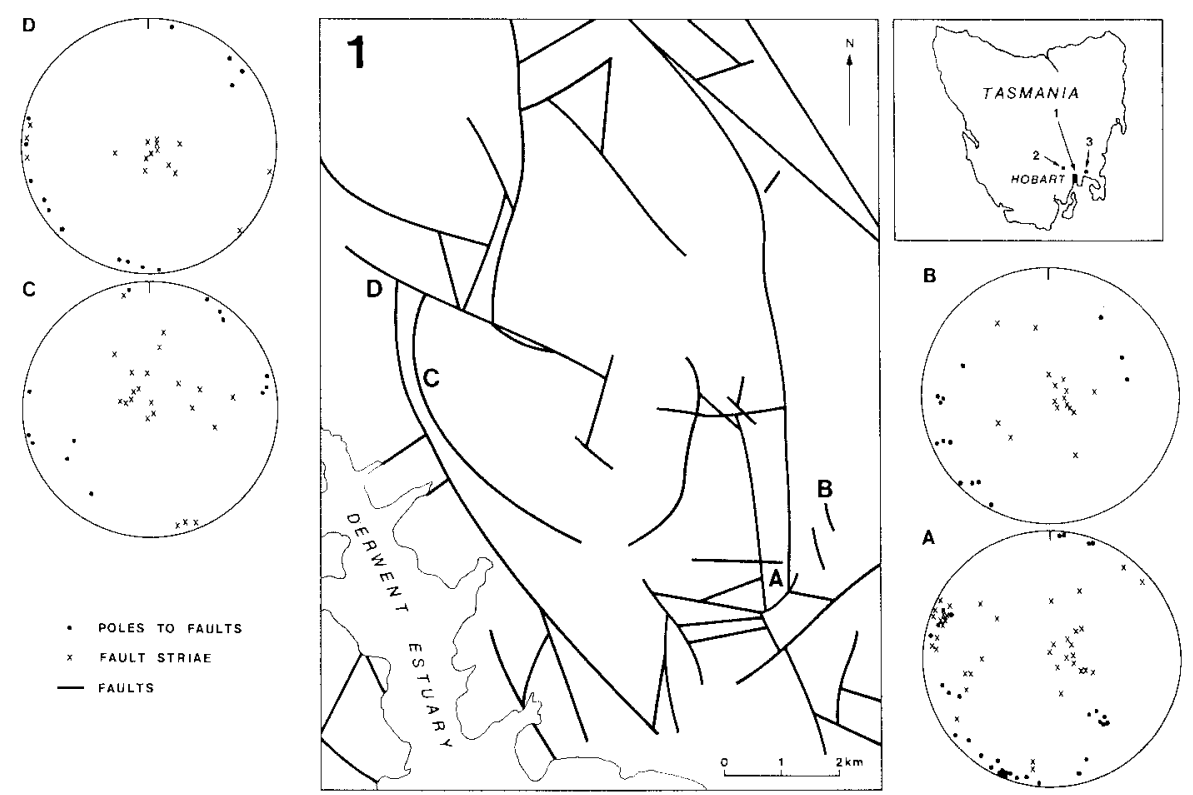

FIG. 2 - Fault striations and fault plane orientations for four localities east of Hobart:- A. Tunnel Hill, B. Cambridge, C. north of Geilston Bay, D. Risd on Brook Dam. Location map in inset. Fault locations from Leaman (1972b).

moderate dips. Few near vertical faults of this strike were observed, in contrast to all other strike orientations.

The entire data set was tested using "STRIA". The method produced two groups of faults, one predominantly composed of dip slip faults and the other predominantly transcurrent faults. In each case the stability of the solution was checked using "STRIA/ TEST" and the groups modified accordingly.

The largest group of fault striations (68) are shown in fig. 1E. The inferred stress system is compatible with the normal sense of slip observed on seven of these faults. The maximum compressive stress $\left(\sigma_{1}\right)$ was near vertical and the two other principal stresses $\left(\sigma_{2}, \sigma_{3}\right)$ nearly the same so that no specific extensional direction can be recognised from the striations. The method gave a slight support for extension to the NE. The orientations of faults in this group are not easily related to these stress directions. We conclude that most of these faults occur along fractures which predate the extensional event.

The second group of 34 fault striations recognised is shown in fig. $1 \mathrm{~F}$. The solution obtained by "STRIA" was compression from the NNW $\left(330^{\circ}\right)$ in a triaxial stress field where $\sigma_{2}$ was vertical. The solution was poorly defined with an estimated accuracy of + ten degrees. In this case we have no direct evidence that the correct solution is compression from the NNW, rather than extension towards the NNW but circumstantial evidence discussed later supports the former solution.

Of the 21 fault striations not represented in these solutions six are poor fits to the second solution and the remaining 15 do not fit either group and do not themselves represent a coherent additional group.

The attempt to model all the striations data in one group assumes a constant regional stress system. In the Hobart area, this may not be an accurate assumption as local variations could be produced by the contrast in rheology between dolerite and the Parmeener Super-group, topography at the time of faulting, and pre-existing fault and joint surfaces. There is sufficient data from six localities to allow independent assessment of the fault striations. The consideration of these small areas, separately, minimizes the problems due to local fluctuations in the stress field.

Forty one fault striations were recorded from Tunnel Hill, Tasman Highway (fig. 2, location A). There are two easily recognisable groups of faults in this area. In the northern part of the outcrop strike slip faults striking $090^{\circ}$ to $120^{\circ}$ are most common. Five fault planes dipping at $45^{\circ}$ to the NW occur at the southern end of the exposure and a nearby large scale fault with the same strike shows a northside up motion (Lea man 1972b). This 
field relationship strongly suggests a reverse motion on these faults. Both these fault sets are compatible with compression from the NW. The expected set of conjugate strike slip faults may be represented by steeply dipping faults striking $290^{\circ}$ to $020^{\circ}$ which, however, now have predominantly dip slip striations. In one case the dip slip motion on one of these faults disrupts strike slip striations.

STRIA was applied to both these groups
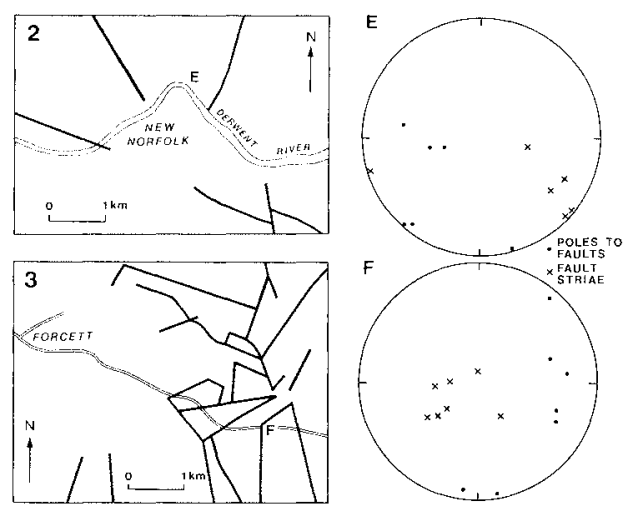

FIG 3 - Fault striations and fault plane orientations for localities $\mathrm{E}$ (New Norfolk) and F (Forcett). Location of maps shown on Fig. 2. Faults shown are from Leaman (1972b) and Gulline (1982).

The former group gives a moderately successful solution compatible with compression from the NW $\left(\sigma_{1}: 0 / 303 ; \sigma_{2}: 85 / 033 ; \sigma_{3}: 5 / 213 ;\left(\sigma_{2}-\sigma_{3}\right) /\left(\sigma_{1}\right.\right.$ $\left.-\sigma_{3}\right)=0.4$ ).

This solution is rotated $24^{\circ}$ anticlockwise from the average solution for the whole area. The latter group of fault striations gave a solution with the extension to the ENE $\left(\sigma_{1}: 50 / 219 ; \sigma_{2}: 9 / 319\right.$; $\left.\sigma_{3}: 39 / 56 ;\left(\sigma_{2}-\sigma_{3}\right) /\left(\sigma_{2}-\sigma_{3}\right)=0.7\right)$. While the calculation was stable for any given selection of faults in this group, the application of STRIA/TEST suggested there was little difference in the closeness of fit between NE and E extension directions from this data.

One kilometre to the NE, locality B, 14 of the 16 fault striations are compatible with normal fault motion on faults dipping $80^{\circ}$ to the ENE and $60^{\circ}$ to the WSW. The two remaining striations were probably formed by NW compression. The low proportion of striations due to the latter stress system implies this area is distant from large scale strike slip faults but the dominance of very steep fault planes implies that many of the extensional faults occur on pre-existing fracture surfaces.

The dip slip fault at this locality were analysed using STRIA. The 14 fault striations fit a stress field which is extensional in all horizontal directions $\left(\sigma_{1}: 67 / 09 ! ; \sigma_{2}: 0 / 182 ; \sigma_{3}: 23 / 272,\left(\sigma_{2}-\sigma_{3}\right) /\left(\sigma_{1}-\sigma_{3}\right)=\right.$ $0.1)$. No preferred extensional direction was found using STRIA/TEST.

At locality $\mathrm{C}, 2 \mathrm{~km}$ north of Geilston Bay, there are both strike slip and dip slip striations, often on the same fault plane. Most of the faults, with near horizontal striations, strike $345^{\circ}$ in contrast with locality A but subparallel to the nearest large fault (fig. 2). Many of these faults also have steeply pitching striations. Some of them have two steeply pitching striations about $20^{\circ}$ apart indicating a complex stress history. Using STRIA/ TEST the fault striations are compatible with extension to the $\mathrm{E}$ or $\mathrm{NE}$.

At the Risdon Brook Dam, Locality D, both strike slip and dip slip faults were observed. The strike slip faults strike $280^{\circ}$ and are subparallel to the major fault to the north. This large fault may have a large strike slip component which is predominantly pre-dolerite, based on the pattern of faults shown for this area on the Hobart sheet (Leaman 1972b). There is one possible conjugate strike slip fault striking $320^{\circ}$. All but two of the dip slip faults have strikes between $320^{\circ}$ and $010^{\circ}$. The most common strike is $330^{\circ}$ and this is subparallel to the large fault to the east (fig. 2). STRIA gave an unstable solution to the steeply pitching striations with a preferred extensional direction towards the NE. STRIA/TEST was also ambiguous and no preferred extension direction was determined.

The remaining two locations are further from Hobart and both have the minimum possible data for a stress analysis. Locality E, near New Norfolk, has a simple pattern of striations which is possibly the result of a single event. Strike slip faults strike $070^{\circ}$ and $130^{\circ}$ suggesting conjugate shears (fig. 3 ). The remaining faults have low to moderate dips. The sense of motion on thee faults could not be determined but joints of the same orientation showed "en passant" relationships (Kranz 1979 , Swan \& Hagan 1978) indicating a normal sense of shear. STRIA gives a good fit to these six faults with extension to ESE $\left(\sigma_{1}: 5 / 189 ; \sigma_{2}: 89 / 009\right.$; $\left.\sigma_{3} 0 / 099,\left(\sigma_{2}-\sigma_{3}\right) /\left(\sigma_{1}-\sigma_{3}\right)=0.7\right)$. The general fault pattern here, and the calculated stress, is compatible with the extensional events. This includes some strike slip faults and suggests some of the strike slip motion on E-W faults may be related to the extension. With the small da ta set available at New Norfolk this result remains provisional. 
Near Forcett, locality F (fig. 3), there is a wide variety of fault orientations but all of them have steeply pitching fault striations. The faults are all compatible with normal faulting and extension towards the NE. Assuming all the striations were produced in a single event, STRIA gave a stable solution with near vertical compression and $\sigma_{2} \cong \sigma_{3}$ so that the extensional direction is not well constrained $\left(\sigma_{1}: 65 / 185, \sigma_{2}: 24 / 024, \sigma_{3}: 7 / 291,\left(\sigma_{2}-\sigma_{3}\right) /\right.$ $\left.\left(\sigma_{1}-\sigma_{3}\right)=0.1\right)$. The large scale fault pattern near this locality shows a $\mathrm{N}$ striking fault to the $\mathrm{W}$ and a $\mathrm{NE}$ striking fault to the $\mathrm{N}$. Both of these orientations are reflected in the fault striations. From our data both fault orientations have $60^{\circ}$ dips to the $W$ compatible with the $\mathrm{W}$ side down and normal motions implied for the large scale faults (Gulline 1982).

Throughout the preceding discussion we have chosen the most likely of two stress systems which are possible for any given set of fault striations where the sense is unknown. In the case of the faults showing extension to the $E$ and NE there is sufficient direct evidence of normal motion to support this model but in the case of compression from the NW the evidence is indirect and less definite.

The presence of faults dipping moderately NW is suggestive of a compressional regime. The angle between strike slip faults is usually acute in the NW quadrant which indicates this is the direction of maximum compressive stress assuming Anderson's (1951) model for strike slip faulting.

On the Hobart map sheet (Leaman, 1972b) there are several examples of probable right lateral displacement on faults striking $100^{\circ}$ (Risdon Vale

Australian Map Grid Zone 55, coordinates $527 / 618,528 / 605$ ) for which our analysis supports a strike slip motion. In combination these features support the interpretation of NW compression over the alternative NW extension.

\section{DISCUSSION \\ Local Significance.}

The movements indicated by fault striations on minor faults support a direct interpretation of the large scale fault pattern near Hobart. East of Hobart the most common fault orientations are striking $100^{\circ}$ and $170^{\circ}$ (fig. 2). From our modelling we conclude these probably formed originally as strike slip faults related to NW compression. The fault pattern in Risdon Vale area fits a right-lateral motion on the faults striking $100^{\circ}$ and strongly suggests much of this motion predates the dolerite intrusion forming Mt. Direction. The NE striking faults to the north of Risdon Vale are inferred to have reverse motion as is the small NE striking fault SE of locality A. The pattern of faults in this area is similar to the experimentally derived pattern of strike slip faults discussed by Freund (1974, fig. 18). He interprets this pattern as the result of sequential development of conjugate faults each of which offsets and locks the pre-existing faults

The extensional faults reported in this study are highly variable in orientation and there is no obvious correlation with the inferred stress direction. In several locations conjugate sets of normal faults exist where one of the sets dips at $60^{\circ}$ while the other dips at $80^{\circ}$ or steeper. Since the extensional faults are probably later (see below) we interpret this as reactivation of steep fractures of suitable orientation which are inherited from the NW compression, and formation of new fractures with dips of approximately $60^{\circ}$ where no suitable fracture orientation were already available. The extensional direction of this event is not well constrained. Features such as the Derwent Graben suggest extension to the ENE. The fault striations we have analysed indica te extension to the NE, E or even ESE. One extra piece of information is effectiveness of reactivation of faults which are presumed to have formed during the NW compressional event. Most of the steep N striking faults are reactivated during this phase but less than half of the steep E striking faults have been reactivated. This strongly supports the conclusion that the main extensional direction was between NE and $\mathrm{E}$.

\section{Relative age of the two fault systems.}

There are several lines of circumstantial evidence that the major extensional event postdates the NW compression. Firstly the dominant fault pattern in the Parmeener Super-group can be interpreted using the Anderson (1951) model for faulting and assuming the faults formed by compression from the N.W. The near vertical faults striking $\mathrm{N}$ and $\mathrm{E}$ are potential strike slip fault directions at less than $45^{\circ}$ to the compression direction where $\sigma_{2}$ is vertical. The small number of low to medium dipping planes striking NE are possible reverse fault orientations. These orientations include the vast majority of faults in the Parmeener Super-group near Hobart. In contrast NW to N striking faults with $60^{\circ}$ dips are a minor component of the faults recorded in this study.

Secondly, the striations on fractures presumably active during both phases of tectonism, a re dominantly of extensional origin suggesting the obliteration of earlier shallowly pitching striations. In one case a fracture with both orientations of stria showed evidence of partial obliteration of the shallowly pitching stria.

Finally, dip slip motion was dominant in the 
formation of the present Derwent Graben. In contrast there is little evidence that strike slip faults have disturbed the present topography. Therefore we conclude that the NNW compressional event occurred before the NE extension.

\section{Regional implications}

The complexity of faulting in the Parmeener Super-group has been recognised by a number of authors. For example Leaman (1972a) recognised three phases of faulting in the Hobart area. A Jurassic event with $\mathrm{N}-\mathrm{S}$ grabens, an Eocene event with NNW striking normal faults and finally a latest Tertiary rejuvenation with $\mathrm{NW}$ strikes most common The significance of strike slip movement has not been recognised in this or other studies of faulting in the Parmeener Super-group.

Forsyth (1984) collected very detailed information on the relationship of faulting to dolerite intrusion in the Oatlands area. He showed conclusively that the orientation of faults active before dolerite intrusion was very similar to that of faults active after the intrusion. Since we have concluded that this fracture pattern was generated by NNW compression, this phase of faulting was active before the Mid Jurassic. In the Risdon Vale area the dolerite is also offset by these faults and nea Tunnel Hill there are faults thought to be of this type cutting the dolerite. These facts imply that the same stress system continued during or after dolerite intrusion.

The extensional tectonics in Hobart region produced the Derwent Graben. Since Palaeocene microfloras have been recorded from this area (Harris 1968), the extensional tectonics began in the Early Tertiary. Thus the provisional data on the relative age of faults in the Hobart area fits the regional structural relations.

The relationship with Victoria and Bass Strait is less clear. Davidson et al. (1984) summarize the structural data from the Bass and Gippsland Basins. They date the extensional phase of faulting as Upper Cretaceous to Middle Eocene in agreement with data from the Derwent Graben. They also recognise reactivation of these structures as strike slip and reverse faults in the latest Eocene to Recent with most activity in the Middle Miocene. Further evidence for NNW compression in the Late Tertiary occurs onshore in Gippsland (Barton 1981) where normal faults have been reactivated as reverse faults and produced draping in La te Tertiary sediments. This stress system probably continues to the present (Worotni \& Denham 1976) although seismic evidence is equivocal (Denham et al. 1981).

Active strike slip and reverse faulting in the Late Tertiary of Bass Strait, suggests similar motions should have occurred in the Hobart region. With the complexity of faulting and limited data in this area, we have not been able to separate out fault striations of this age from the group produced in the Mesozoic. The weight of evidence near Hobart is that the fault striations related to NNW compression are pred ominantly of Mesozoic age but we cannot exclude the possibility that a substantial proportion of them formed in the Late Tertiary.

\section{CONCLUSIONS}

The movement history of the faults within the Parmeener Super-group is preserved by fault striations on small faults and fractures near them. Several major faults within the Group have had strike slip motion before the extensional, normal motion which produced the Derwent Graben Close attention to the fault striations, combined with sophisticated numerical modelling, indicates the stress system at each stage of the fault motion. This data can be combined to generate a coherent model of the tectonic history of the Group near Hobart.

A major NNW compressinal event in the Mesozoic established a fracture pattern with strike slip faults striking $100^{\circ}$ and $170^{\circ}$, and reverse faults striking NE. This event was active before and after the intrusion of dolerite in the Jurassic. A subsequent phase of faulting, Early to Middle Tertiary, produced the Derwent Graben by general E to NE extension predominantly by reactivation of faults established in the Mesozoic. The nature of Late Tertiary faulting remains in doubt.

\section{REFERENCES}

ANDERSON, E.M., 1951: THE DYNAMICS OF FAULTING. Oliver \& Boyd, Edinburgh, 206pp.

ANGELIER, J.: Tectonic a nalysis of fault slip data sets. J. Geophys. Res., 89:5835-5848

ANGELIER, J., COLLETTA, B., CHOROWICZ, J., ORTLIEB, L \& RANGIN, C., 1981: Fault tectonics of the Baja California Peninsula and the opening of the Sea of Cortez, Mexico. $J$ Structural Geol., 3: 347-357.

ARMIJO, R. \& CISTERNAS, A., 1978: Un probleme inverse en microtectonique cassante. C. r. hebd. Seanc. Acad. Sci. Paris 287: 595-598.

BANKS, M.R., 1962: Permian. In SPRY, A.H. \& BANKS, M.R. (Eds): THE GEOLOGY OF TASMANIA. J. Geol. Soc. Aust., 9(2): 189-215.

BARTON, C.M., 1981: Regional stress and structure in relation to brown coal open cuts of the Latrobe Valley, Victoria. J. Geol. Soc. Aust., 28: 333-339.

CAREY, E. \& BRUNIER, B., 1974: Analyse theorique et numerique d'un modele mecanique elementaire applique a l'etude d'une population de failles. $C$. r. hebd. Seanc. Acad. Sci., Paris 279: 891-894. 
DAVIDSON, J.K., BLACKBURN, G.J. \& MORRISON, K.C., 1984: Bass and Gippsland Basins: a comparison. APEA J., 24: 101-109.

DENHAM, D., WEEKES, J. \& KRAYSHEK, C., 1981: Earthquake evidence for compressive stress in the southeast Australian crust. J. Geol. Soc Aust., 28: 323-332.

ETCHECOPAR, A., VASSEUR, G., \& DAIGNIERES, M., 1981: An inverse problem in microtectonics for the determination of stress tensors from fault striation analysis. J. Structural Geol., 3: 51-65.

EVERNDEN, J.F. \& RICHARDS, J.R., 1962: Potassium-argon ages in eastern Australia. $J$. Geol. Soc. Aust. 9: 1-50.

FORSYTH, S.M., 1984: Geological Atlas 1:50 000 Series, Zone 7, Sheet 68, Oatlands. Explan. Rept Geol. Surv. Tasm.

FREUND, R., 1974: Kinematics of transform and transcurrent faults. Tectonophysics, 21:93-134.

GULLINE, A.B. 1982: Geological Atlas 1:50,000 series. Sheet 8312 S Sorell. Department of Mines, Tasmania.

HARRIS, W.K., 1968: Tasmanian Tertiary and Quaternary microfloras. Summary report. Palaeont Rep. Geol. Surv. S. Aust. 5/68.
KRANZ, R.L., 1979: Crack-crack and crack-pore interactions in stressed granite. Int. J. Rock Mech. Min. Sci. Geomech. Abstr., 16:37.47

LEAMAN, D.E., 1972a: Gravity Survey of Hobart District. Tas. Dept. Mines Geol. Survey Bull. 52

LEAMAN, D.E. 1972b: Geological Atlas 1:50,000 series. Sheet 8312 S Hobart. Department of Mines. Tasmania.

McDOUGALL, 1., 1961: Determination of the age of a basic igneous intrusion by the potassium-argon method. Nature, 190: 1184-1186.

MOORE, W.R., BAILLIE, P.W., FORSYTH, S.M. HLDSPETH, J.W., RICHARDSON, R.G. \& TURNER, N.J., 1984: Boobyalla Sub-basin: A Cretaceous onshore extension of the southern edge of the Bass Basin. APEA J., 24: 110-117.

SWAIN, M.V.\& HAGAN, J.T., 1978: Some observations of overlapping interacting cracks. Engng. Fract. Mech., 10: 299-304.

WOROTNICKI, G. AND DENHAM, D., 1976: The state of stress in the upper part of the Earth's crust in Aust. According to measurements in mines and tunnels and from seismic observations. Symposium on Investigation of Stress in Rock. Inst. of Engineers, I.S. R.M., Sydney 71-82.

(accepted Feb 21, 1985) 